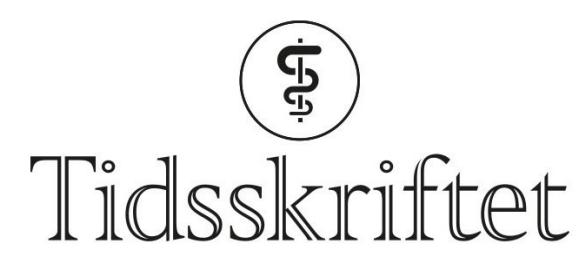

DEN NORSKE LEGEFORENING

\title{
Lauritz Bredrup Dahl
}

MINNEORD

CLAUS KLINGENBERG

PER IVAR KAARESEN

MARIANNE NORDHOV

TROND FLAEGSTAD

GUDMUND MARHAUG

HANS PETTER FUNDINGSRUD

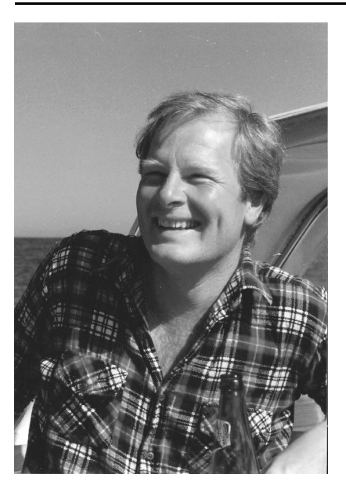

Vår gode venn, kollega og mentor Lauritz (Lasse) Bredrup Dahl døde 76 år gammel 9. august 2018.

Lasse ble født og vokste opp i Oslo, men tilhørte Mack-Bredrup familien fra Tromsø. Han studerte medisin i Basel og traff der sin kjære Rie. I 1971 kom Lasse «hjem til Tromsø» og han startet i 1972 som ung lege på Barneavdelingen ved Regionsykehuset i Troms $\emptyset$. Lasse var en dyktig barnelege og fikk tidlig ansvaret for nyfødtavdelingen. Sammen med en entusiastisk stab av leger og sykepleiere bygde han opp nyfødtavdelingen til en moderne enhet som ga omsorg på høyt nivå til de minste og sykeste nyfødte fra Troms og Finnmark. Oppfølging av barn med hjertefeil var et annet område der Lasse gjorde en stor innsats. Mange foreldre var svært takknemlige for å bli trygt ivaretatt av en barnelege med stor klinisk kompetanse og erfaring.

Lasse arbeidet ved barneavdelingen i Troms $\emptyset$ til han gikk av med pensjon i 2010. Han var en bauta som representerte kontinuitet $\mathrm{i}$ en avdeling som i hans tid vokste til å bli en moderne universitetsavdeling. Som kliniker var han kompetent, trygg og rolig selv i de mest akutte 
situasjoner med kritisk syke nyfødte. Som veileder og kollega var han en ekstremt viktig støttespiller. Han ga gode råd til yngre kolleger, alltid med et glimt i øyet. Mange ønsket å jobbe under Lasses ledelse, og storsinnet mente han at definisjonen på god ettervekst var «å la andre bli bedre enn deg selv, mens du selv er til stede».

Lasse var også professor i pediatri ved Universitetet i Tromsø. Han var en meget populær lærer. De siste 12 årene av yrkeskarrieren ledet han et stort forskningsprosjekt om for tidlig fødte barn. Han var en visjonær i tverrfaglig samarbeid, og han forsto at hele familien til disse sårbare barna må ivaretas. I forskningsprosjektet veiledet han også flere doktorgradskandidater, og resultatene fra prosjektet skapte stor interesse både nasjonalt og internasjonalt.

Aller viktigst for Lasse var imidlertid familien hjemme: Rie og barna. Våre varmeste tanker går til den nærmeste familie som har mistet en høyt elsket ektemann, far og bestefar.

Publisert: 14. januar 2019. Tidsskr Nor Legeforen. DOI: 10.4045/tidsskr.18.0897

(C) Tidsskrift for Den norske legeforening 2020. Lastet ned fra tidsskriftet.no 